\title{
Work from Home: Determinant of Individual Learning for Lecturers-Student
}

\author{
Reni Shinta Dewi ${ }^{1}$, Dinalestari Purbawati ${ }^{2}$, Robetmi Jumpakita Pinem ${ }^{3}$ \\ \{renishinta@yahoo.co.id ${ }^{1}$ \} \\ Universitas Diponegoro, Indonesia ${ }^{1,2,3,4,5}$
}

\begin{abstract}
The spread of Covid-19 throughout the world prompted the WHO to establish a pandemic status. This condition is also experienced by Indonesia, where 187,537 people died. This situation encourages the government to make policies in the form of social distancing through the work from home (WFH) program. No exception, the Ministry of Education determines the status of WFH from early childhood education to higher education. For higher education, e-learning has become a program in the development of learning, especially in the 4.0 era. However, not all lecturers and students have the capability in e-learning. The purpose of this research is to explore individual learning for lecturers and students in the context of WFH. The research was carried out throughout Indonesia by distributing questionnaires via a google form. The distribution is carried out for 6 (six) weeks, through various networks. The responses from distributing questionnaires were 420 respondents. Data analysis was performed using factor analysis through SPSS. The results show that all the items analyzed can explain the factors forming the Individual Learning variable. There are 3 (three) forming factors, self-directedness, acquiring, and applying new knowledge, and realizing learning opportunities.
\end{abstract}

Keywords: Individual Learning, Self-Directedness, New Knowledge, Learning Opportunities

\section{Introduction}

The World Health Organization (WHO) has categorized the new coronavirus or coronavirus disease 2019 (Covid-19) as a pandemic because the virus has spread widely throughout the world. The determination of Covid-19 as a global pandemic was carried out after there were more than 22 million cases of coronavirus infection in more than 200 countries, including Indonesia [1]. Indonesia itself until August 20, 2020, the number of Covid-19 cases was 147,211 , with details of 40,119 people being treated, 100,674 recovered, and 6,418 people died [1].

The increase in the number of deaths with Covid-19 has led the government to issue a social distancing scheme, reducing interaction between people in the community and public spaces. The main objectives are reducing the size of the outbreak, delaying the peak of the epidemic, and distributing the number of infected people in a longer period so that the burden on the health system is reduced [2]. To implement social distancing, the government issued a policy to implement work at home (Work from Home-WFH) [2]. This policy is no exception as the basis for the Ministry of Education and Culture in issuing the Minister of Education and Culture Circular Number 3 of 2020 concerning the Prevention of COVID-19 in the Education Unit, and Number 36962/MPK.A/HK/2020 concerning Online Learning and Working from 
Home at Home. Prevention of the Spread of Corona Virus Disease (Covid-19) [3]. Minister of Education Nadiem Makarim invited teachers and lecturers to also work from home or work from home. Nadiem conveyed that teaching activities can be done from home using technology $[2]$.

Based on this regulation, all universities in Indonesia began implementing WFH for both lecturers and students starting March 16, 2020. The implementation of WFH was carried out through online media such as MS. Teams, Edmodo, ZOOM, Google Classroom, Skype, and others to support the implementation. teaching and learning process. However, the reality in the field is that not all lecturers and students can use online learning media. In a short time, they are required to be able and able to run online learning programs. It takes a willingness to learn individually from both lecturers and students.

This is in line with Skinner's Learning Theory, where learning is a function of open behavior change. Behavior change is the result of an individual's response to events (stimuli) that occur in the environment [3]. This response will shape the learning experience of each individual through interactions with organizational members [3]. The learning experience of each member leads to individual abilities, which shows that individual learning is the most important competency for organizational success [4]. Individual learning includes all behaviors and is related to the acquisition of knowledge, attitudes, values, and emotional responses [4].

Individual learning is an important element for improving individual performance because it will increase competence to a higher level for the achievement of organizational goals [5]. The existence of WFH lecturers and students is required to individually be able to learn through experience in carrying out online learning. The main contribution of this research is to explore individual learning, especially in online learning models during the Covid-19 pandemic.

\section{Conceptual Framework}

Modern learning theories from the cognitive-constructivist paradigm assume that learning involves an iterative process in structuring, refining, and restructuring mental models [6]. These processes are combined related to other learning such as the use of common sense, debugging, evaluation, reflection, and many more. All of these processes are necessary for meaningful learning and are used in the context of individual learning [6]. Cognitive learning theory [7] states that individual learning supports actual behavior change and encourages adaptation to environmental conditions. Individuals may be more motivated [8] through individual learning. [9], describing learning as a relatively permanent change in knowledge or skills generated by experience suggests that one must take into account the potential change in behavior represented in learning.

Researchers investigating individual learning have noted that such learning involves personal development and changes in behavior, attitudes, or even personality. Individual learning is characterized by the transformation of individuals who see themselves as other people and require sophisticated interpersonal skills [10]. These skills are very important to help individuals develop and help increase efficiency and productivity, and meet individual personal and career development needs [1].

Learning is a continuous and strategic process. Learning is defined as a process in which individuals acquire new knowledge and insights that result in changes in behavior and actions [11]. The learning subsystem consists of three complementary dimensions: level of learning (individual, group, and organization), type of learning (adaptive, anticipatory, and action), and skills (thinking systems, mental models, personal mastery, independent learning, and dialogue). 
Individual learning has utilitarian goals because it is seen as a system-oriented to developing knowledge that helps people survive and adjust to the constant changes affecting their organizations [11]. Senge [12] asserts that "organizations only learn through individuals who learn. Individual learning does not guarantee organizational learning, but without it, no organizational learning occurs". Senge [12] agrees that "learning is not much related to retrieving information, on the contrary, learning is a capacity building process. Learning is about building the ability to act to create what you could not previously create. Ames and Archer [13], identify four sub-dimensions related to individual learning that should help to better understand individual learning as a concept. These sub-dimensions are as follows: 1) Seeing, Finding, and Realizing Learning Opportunities; 2) Acquiring and Applying New Knowledge; 3) SelfDirectedness (self-study); and, Continuous Learning.

\section{Research Methods}

This type of research is a quantitative survey and was conducted cross-sectional for three months. Distribution of questionnaires via Google Form, which is distributed through the author's network of friends. After 6 (six) weeks, there were 420 responses from lecturers and students from all over Indonesia who were implementing e-learning. Data were analyzed using the Statistical Package for Social Sciences (SPSS) for statistical analysis. Factor analysis was carried out on four sub-dimensions of individual learning with 17 items using principal components analysis and Varimax-Rotation. The 5-point Likert Scale is used to measure the four sub-dimensions of individual learning from Ames and Archer [13].

\section{Result and Discussion}

This study involved the participation of lecturers (30.7\%) and students (69.3\%). The online learning media used are as shown in the graph 1.

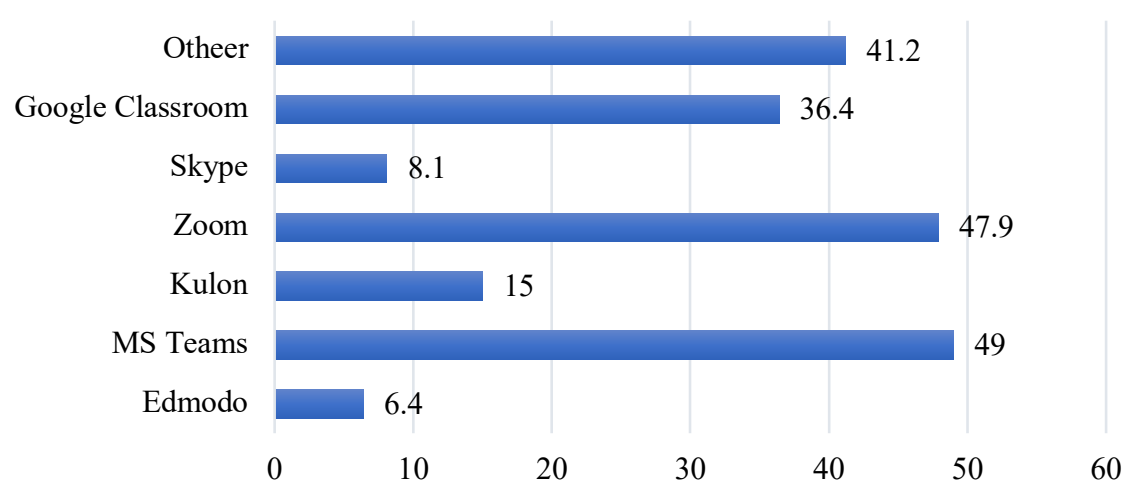

Fig. 1. Online Media Learning.

Factor analysis was used to test 17 factors constituting individual learning. The solution of the three factors was obtained by extracting factors with the eigenvalue more than 1 , which explained 62.415 percent variants (statistic Kaiser-Meyer-Olkin 0.865; Bartlett test of 
specificity 4173.048; the significance of 0.000). The loading factor was shown in Table I. Loading factor in each factor exceeded 0.50 .

Table 1. Analysis Factor

\begin{tabular}{|c|l|c|c|c|}
\hline & \multicolumn{2}{|c|}{ Factor 1 } & Factor 2 & Factor 3 \\
\hline 1 & Improved learning skills & & .803 & \\
\hline 2 & Gain new knowledge & & .902 & \\
\hline 3 & $\begin{array}{l}\text { Better to do the assignment individually (not as } \\
\text { part of a team) }\end{array}$ & .857 & \\
\hline 4 & Improved my understanding & & .657 & \\
\hline 5 & E-learning more challenging & & .719 \\
\hline 6 & Continuous learning & & .817 \\
\hline 7 & Felt more prepared & .730 & & \\
\hline 8 & I'd like to have individual assignments & .754 & & \\
\hline 9 & The grade reflects my knowledge & .733 & & \\
\hline 10 & $\begin{array}{l}\text { I think that e-learning contributes to learning } \\
\text { more than other learning methods }\end{array}$ & .584 & & \\
\hline 11 & The instructor comments are more significant to \\
my learning & .671 & & \\
\hline 12 & $\begin{array}{l}\text { Increased my confidence in mastering the } \\
\text { learning materials }\end{array}$ & .560 & & \\
\hline 13 & The instructor comments address my work & .672 & & \\
\hline 14 & Increases the motivation to learn & .833 & & \\
\hline 15 & Changes in behavior & .547 & & \\
\hline 16 & More time to doing the assignment & .834 & & \\
\hline 17 & I took more seriously & .838 & & \\
\hline
\end{tabular}

The analysis result of factors towards individual learning was in line with the research conducted by Ames and Archer [13] consisting of three factors:

1. Factor 1 represented recognizing learning opportunities.

2. Factor 2 was Apply New Knowledge.

3. Factor 3 was Self-Directedness.

These findings support the learning theory which states that learning is a continuous and strategic process that is integrated with work. Marquardt [11] argues that individual learning has utilitarian goals because it is seen as a system-oriented to develop knowledge that helps people survive and adjust to the constant changes affecting their organization.

Learning has generally been studied in the context of information seeking during socialization [14]. In socialization studies, learning focuses on finding three types of information: technical (about how to do tasks); references (about what other people expect from them); and normative (about expected behavior and attitudes) [14]. Researchers investigating individual learning have noted that such learning involves personal development and changes in behavior, attitudes, or even personality [14]. Individual learning is characterized by the transformation of individuals who see themselves concerning other people and require sophisticated interpersonal skills [10]. These skills are very important to help individuals develop and help increase efficiency and productivity, and meet individual personal and career development needs [15]. 


\section{Conclusion}

Cognitive learning theory [7] states that individual learning supports actual behavior change and promotes adaptation to environmental conditions. Individuals may be more motivated [8] through individual learning. Weiss [9] describing learning as a relatively permanent change in knowledge or skills produced by experience suggests that one must take into account the potential change in behavior represented in learning.

The limitation of this research is using a cross-sectional method that didn't see the development of individual learning in a comprehensive. Future research, make a comparison between individual learning and cooperative learning.

\section{References}

[1] Worldometers, "Covid-19 Coronavirus Pandemic," Worldometers, 2020. [Online]. Available: https://www.worldometers.info/coronavirus.

[2] S. W. Wibawa, "Corona Outbreak in Indonesia, Experts Warn the Dangers of Halfhearted Social Distancing," Kompas.com, 2020. .

[3] P. M. Panayides, "The impact of organizational learning on relationship orientation, logistics service effectiveness and performance," Ind. Mark. Manag., vol. 36, no. 1, pp. 68-80, 2007.

[4] J. Mehrabi, M. Jadidi, F. A. Haery, and M. Alemzadeh, "The relationship between organizational commitment and organizational learning (Boroojerd Telecommunication Company as case study)," Int. J. Acad. Res. Bus. Soc. Sci., vol. 3, no. 1, p. 130, 2013.

[5] A. R. Ahmad and A. Marinah, "Learning organization and organizational commitment in schools," J. Res. Policy Pract. Teach. Teach. Educ., vol. 3, no. 1, pp. 18-25, 2013.

[6] A. Yadin and R. Or-Bach, "The importance of emphasizing individual learning in the “collaborative learning era,'” J. Inf. Syst. Educ., vol. 21, no. 2, pp. 185-194, 2010.

[7] K. D. Duncan and C. J. Kelly, Task analysis, learning and the nature of transfer. Manpower Services Commission, Training Division, 1983.

[8] S. Sonnentag, C. Niessen, and S. Ohly, "Learning at work: training and development," Int. Rev. Ind. Organ. Psychol., vol. 19, pp. 249-290, 2004

[9] H. M. Weiss, "Learning theory and industrial and organizational psychology," 1990.

[10] S. B. Merriam and B. Heuer, "Meaning-making, adult learning and development: a model with implications for practice," Int. J. Lifelong Educ., vol. 15, no. 4, pp. 243-255, 1996.

[11] M. J. Marquardt, Building the learning organization: A systems approach to quantum improvement and global success. McGraw-Hill Companies, 1996.

[12] P. M. Senge, The fifth discipline: The art and practice of the learning organization. Currency, 2006.

[13] C. Ames and J. Archer, "Achievement goals in the classroom: Students' learning strategies and motivation processes," J. Educ. Psychol., vol. 80, no. 3, p. 260, 1988.

[14] E. W. Morrison, "Newcomer information seeking: Exploring types, modes, sources, and outcomes," Acad. Manag. J., vol. 36, no. 3, pp. 557-589, 1993.

[15] C. Panari, D. Guglielmi, S. Simbula, and M. Depolo, "Can an opportunity to learn at work reduce stress?," J. Work. Learn., 2010. 